\title{
Marinitoga litoralis sp. nov., a thermophilic, heterotrophic bacterium isolated from a coastal thermal spring on Île Saint-Paul, Southern Indian Ocean
}

Correspondence

Anne Postec

anne.postec@univmed.fr

\author{
Anne Postec, † Maria Ciobanu, Jean-Louis Birrien, Nadège Bienvenu, \\ Daniel Prieur and Marc Le Romancer
}

UMR6197, Laboratoire de Microbiologie des Environnements Extrêmes, IUEM, Technopôle BrestIroise, F-29280 Plouzané, France
Members of the order Thermotogales are thermophilic and heterotrophic bacteria that grow under anaerobic conditions. They consume diverse organic substrates and may reduce sulfur compounds. At the time of writing, the order Thermotogales included six genera: Thermotoga, Thermosipho, Fervidobacterium, Petrotoga, Geotoga and Marinitoga. Members of these genera have been isolated from various extreme environments: Geotoga and Petrotoga species have been found only in oil reservoirs (Ollivier \& Cayol, 2005), whereas Thermotoga and Thermosipho species have been isolated from hot ecosystems throughout the world (e.g. terrestrial thermal springs, oceanic hydrothermal vents). Within the genus Marinitoga, four species have been characterized to date: Marinitoga camini, M. piezophila, M. hydrogenitolerans and M. okinawensis (Wery

tPresent address: IRD UMR D180, Laboratoire de Microbiologie et Biotechnologie des Environnements Chauds, ESIL case 925, 163 avenue de Luminy, 13288 Marseille cedex 9, France.

The GenBank/EMBL/DDBJ accession number for the 16S rRNA gene sequence of strain $\mathrm{MC}^{\top}$ is FM253687.

Transmission and scanning electron micrographs of cells of strain $\mathrm{MC}^{\top}$ are available as supplementary material with the online version of this paper. et al., 2001a; Alain et al., 2002; Postec et al., 2005; Nunoura et al., 2007). They all originated from deep oceanic hydrothermal vents and one of them has been described as piezophilic (Alain et al., 2002). Here, the isolation and characterization are described of a novel bacterium belonging to the genus Marinitoga, the first to be isolated from a coastal thermal spring. Considering its phenotypic and genetic characteristics, the novel strain is proposed as a representative of a novel species of the genus Marinitoga.

A thermal spring was sampled on Île Saint-Paul $\left(38^{\circ} 43^{\prime} \mathrm{S}\right.$ $77^{\circ} 31^{\prime} \mathrm{E}$ ), located in the South Indian Ocean and belonging to the French Southern and Antarctic Lands. Île Saint-Paul is a $6.5 \mathrm{~km}^{2}$ island corresponding to the emerged part of a partially sunk volcano. The central crater is $1.6 \mathrm{~km}$ in diameter and forms a protected lagoon. In the intertidal zone, water mixed with sediment was collected from a thermal spring. The $\mathrm{pH}$ measured in situ was 6.2, the temperature was $54-57^{\circ} \mathrm{C}$ and conductivity was $51 \mu \mathrm{S}$ $\mathrm{cm}^{-1}$. Samples were stored anaerobically in sterile glass bottles at $4{ }^{\circ} \mathrm{C}$ and later used as inocula at $2 \%(\mathrm{v} / \mathrm{v})$. Enrichment cultures were performed at $60{ }^{\circ} \mathrm{C}$ on the following medium, modified from Ravot et al. (1995) $\left(1^{-1}\right)$ : $0.3 \mathrm{~g} \mathrm{NH}_{4} \mathrm{Cl}, 0.5 \mathrm{~g} \mathrm{MgCl}_{2} .6 \mathrm{H}_{2} \mathrm{O}, 0.1 \mathrm{~g} \mathrm{CaCl}_{2} .2 \mathrm{H}_{2} \mathrm{O}, 0.5 \mathrm{~g}$ 
$\mathrm{KCl}, 0.83 \mathrm{~g}$ sodium acetate trihydrate, $2 \mathrm{~g}$ yeast extract (Difco), 2 g Biotrypcase (Difco), 2 g maltose, 30 g sea salts, 3.3 g PIPES, $1 \mathrm{ml}$ polyvitamin solution (Balch et al., 1979) and $1 \mathrm{mg}$ resazurin (all compounds from Sigma unless otherwise indicated). The medium was prepared anaerobically and the gas phase was $100 \% \mathrm{~N}_{2}$. The $\mathrm{pH}$ was adjusted to 6.0 before autoclaving for $20 \mathrm{~min}$ at $121{ }^{\circ} \mathrm{C}$. The medium was then reduced with $0.5 \mathrm{~g} \mathrm{Na}_{2} \mathrm{~S} .9 \mathrm{H}_{2} \mathrm{O}$ and sterile sulfur was added. Cell growth was observed and isolation was performed by repeated dilution-to-extinction in series. Single colonies were obtained by streaking on the same medium solidified with $15 \mathrm{~g}$ Gelrite $\mathrm{l}^{-1}$. One isolate, referenced as strain $\mathrm{MC}^{\mathrm{T}}$, is described in this study. Purity of the strain was routinely confirmed by microscopic examination.

Morphological characteristics of strain $\mathrm{MC}^{\mathrm{T}}$ cells were determined by optical microscopy (Olympus CX40), transmission electron microscopy (JEOL JEM 100 CX II) and scanning electron microscopy (FEI Quanta 200). Cells were Gram-negative, motile rods; no spore formation was detected. During exponential phase, they appeared singly or in pairs with a polar flagellum and they divided by constriction. Cells were $0.8-1.0 \times 1.0-2.4 \mu \mathrm{m}$. During stationary phase, cells became elongated and reached $7.0 \mu \mathrm{m}$ long (Supplementary Fig. S1, available in IJSEM Online). Chains containing up to five cells were observed and togas were visible.

Physiological characterization of the novel isolate was carried out using the medium modified from Ravot et al. (1995). Methods for determination of growth parameters were as described previously (Wery et al., 2001b). All experiments were performed in triplicate. Bacterial growth was monitored in culture tubes by spectrometry at $600 \mathrm{~nm}$. Cell count correlations with optical density measurements were determined using a Thoma chamber. The temperature range for growth at $\mathrm{pH} 6.0$ was $45-70{ }^{\circ} \mathrm{C}$, with optimum growth at $60{ }^{\circ} \mathrm{C}$. The $\mathrm{pH}$ range for growth at $60{ }^{\circ} \mathrm{C}$ was 5.5-7.5, with optimum growth at $\mathrm{pH}$ 6. Growth was not observed at temperatures $\leqslant 37$ or $\geqslant 75{ }^{\circ} \mathrm{C}$, or at $\mathrm{pH} \leqslant 4.8$ or $\geqslant 8.1$. The $\mathrm{NaCl}$ range for growth at $\mathrm{pH} 6$ and $60{ }^{\circ} \mathrm{C}$ was $8-46 \mathrm{~g} \mathrm{NaCl} \mathrm{l}^{-1}$, with optimum growth at $26 \mathrm{~g}$ $1^{-1}$. No growth was observed in the absence of $\mathrm{NaCl}$ or at $\mathrm{NaCl}$ concentrations $\geqslant 52 \mathrm{~g} \mathrm{l}^{-1}$. Under optimal growth conditions, the maximum cell density reached $5.6 \times 10^{8}$ cells $\mathrm{ml}^{-1}$ and the maximal growth rate was $0.48 \mathrm{~h}^{-1}$, corresponding to a mean generation time of $1.44 \mathrm{~h}$.

Strain $\mathrm{MC}^{\mathrm{T}}$ is an obligate chemo-organotroph. No growth was detected on minimal medium with $\mathrm{H}_{2} / \mathrm{CO}_{2}(80 / 20)$ as a gas phase. The ability of the isolate to use various carbon sources was tested using the mineral base of the modified Ravot medium described above with $0.2 \mathrm{~g}$ yeast extract $\mathrm{l}^{-1}$ as sole organic carbon. The following carbohydrates were tested at $5 \mathrm{~g} \mathrm{l}^{-1}$ : cellobiose, fructose, galactose, glucose, glycogen, glycerol, lactose, maltose, ribose and starch. The following organic substrates were tested at $2 \mathrm{~g} \mathrm{l}^{-1}$ : acetate, brain heart infusion, Casamino acids, casein, formate, peptone, propionate, pyruvate, succinate, tryptone and yeast extract. A cell pellet of a preculture was washed twice with modified Ravot medium depleted in carbon source and was then used as inoculum. Each substrate was tested in duplicate. Positive cultures were confirmed by subcultures on the same medium. Medium without added organic compound was used as a negative control. Cultures were incubated at $60{ }^{\circ} \mathrm{C}$ and growth was monitored by microscopic observation after $24 \mathrm{~h}$ of cultivation. Compared with the negative control, growth was enhanced by cellobiose, galactose, glucose, glycogen, lactose, maltose, ribose, starch, brain heart infusion, Casamino acids, casein, peptone, pyruvate, tryptone and yeast extract.

Nitrogen sources were tested in duplicate on modified Ravot medium lacking yeast extract, Biotrypcase and $\mathrm{NH}_{4} \mathrm{Cl}$. Compared with a negative control that lacked any nitrogen sources, growth occurred in the presence of gelatin $\left(2 \mathrm{~g} \mathrm{l}^{-1}\right)$, glutamate $\left(2 \mathrm{~g} \mathrm{l}^{-1}\right)$, urea $\left(2 \mathrm{~g} \mathrm{l}^{-1}\right)$, $\mathrm{NaNO}_{3}(20 \mathrm{mM})$ and $\mathrm{NH}_{4} \mathrm{Cl}(20 \mathrm{mM})$.

The use of several sulfur compounds by strain $\mathrm{MC}^{\mathrm{T}}$ was tested in duplicate using modified Ravot medium. Elemental sulfur $\left(5 \mathrm{~g} \mathrm{l}^{-1}\right)$, L-cystine $(20 \mathrm{mM})$ and thiosulfate $(20 \mathrm{mM})$ slightly enhanced growth of strain $\mathrm{MC}^{\mathrm{T}}$. In the presence of elemental sulfur, $\mathrm{H}_{2} \mathrm{~S}$ production was detected, using a method described elsewhere (CordRuwisch, 1985).

Growth of strain $\mathrm{MC}^{\mathrm{T}}$ cultivated on modified Ravot medium was tested separately with and without elemental sulfur in the presence of various gas phases: $\mathrm{N}_{2}(100 \%)$, $\mathrm{H}_{2} / \mathrm{CO}_{2}(80 / 20)$ and $\mathrm{H}_{2}(100 \%)$. Growth was not affected by $\mathrm{H}_{2}$ concentration and similar maximal cell densities were obtained in each case. Strain $\mathrm{MC}^{\mathrm{T}}$ tolerated up to

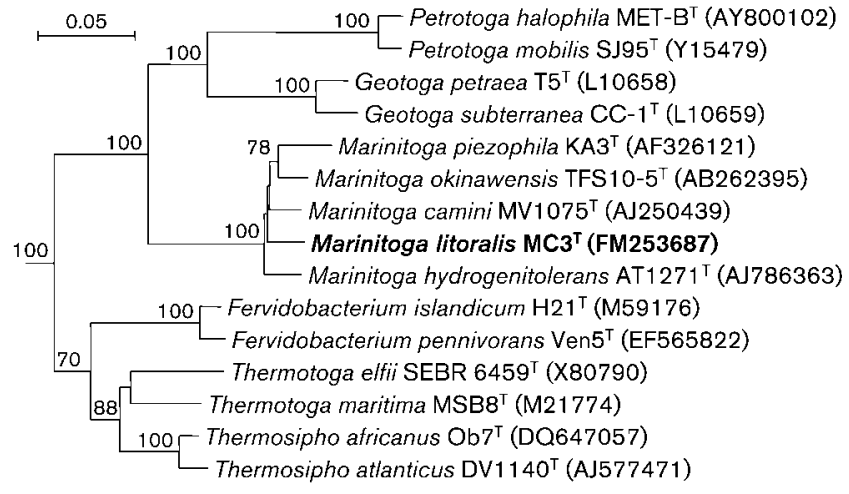

Fig. 1. Phylogenetic tree based on 16S rRNA gene sequences showing the position of strain $\mathrm{MC}^{\top}{ }^{\top}$ among members of the order Thermotogales. A total of 1204 sites were used for the phylogenetic analysis. Accession numbers are indicated in parentheses. The topology corresponds to an unrooted tree obtained by the neighbour-joining method. Numbers at nodes indicate bootstrap values above $70 \%$ from 500 replications. Bar, 0.05 substitutions per nucleotide position. 
$2 \%$ oxygen in the gas phase, but growth was inhibited in $4 \%$ oxygen.

Genomic DNA of strain $\mathrm{MC}^{\mathrm{T}}$ was extracted as described by Wery et al. (2001a). The $\mathrm{G}+\mathrm{C}$ content of the genomic DNA was determined as $26.2 \mathrm{~mol} \%$ at the DSMZ (Braunschweig, Germany) using HPLC (Shimadzu) as described by Mesbah et al. (1989).

The 16S rRNA gene was selectively amplified and sequenced as described by Wery et al. (2001b). The sequence was then compared with available sequences in GenBank using a BLAST search (Altschul et al., 1990). A multiple sequence file was generated using the program BioEdit. Alignments and similarity levels were obtained by the Clustal w method (Thompson et al., 1994). Alignments were manually refined using BioEdit and the phylogenetic reconstruction was performed using PHYLO_WIN (Galtier et al., 1996) with the following algorithms: neighbour-joining method with Jukes-Cantor corrections (Saitou \& Nei, 1987), and maximum-parsimony and maximum-likelihood methods (Felsenstein, 1981). Bootstrap values were determined as described by Felsenstein (1985). Strain $\mathrm{MC}^{\mathrm{T}}$ was affiliated phylogenetically to the genus Marinitoga, order Thermotogales

Table 1. Characteristics of members of the genus Marinitoga

Strains: 1, Marinitoga litoralis sp. nov. MC3 ${ }^{\mathrm{T}}$ (data from this study); 2, M. hydrogenitolerans AT1271 ${ }^{\mathrm{T}}$ (Postec et al., 2005); 3, M. okinawensis TFS10$5^{\mathrm{T}}$ (Nunoura et al., 2007); 4, M. camini MV1075 ${ }^{\mathrm{T}}$ (Wery et al., 2001a); 5, M. piezophila KA3 ${ }^{\mathrm{T}}$ (Alain et al., 2002). +, Positive; -, negative; $(+$ ), weakly positive; ND, no data available.

\begin{tabular}{|c|c|c|c|c|c|}
\hline Characteristic & 1 & 2 & 3 & 4 & 5 \\
\hline \multicolumn{6}{|l|}{ Strain isolation } \\
\hline Origin $^{\star}$ & SIO (Île Saint-Paul) & MAR (Rainbow) & sот (Yonaguni Knoll IV) & MAR (Menez-Gwen) & EPR (Grandbonum) \\
\hline Latitude & $38^{\circ} 43^{\prime} \mathrm{S}$ & $36^{\circ} 13^{\prime} \mathrm{N}$ & $24^{\circ} 51^{\prime} \mathrm{N}$ & $37^{\circ} 51^{\prime} \mathrm{N}$ & $12^{\circ} 48^{\prime} \mathrm{N}$ \\
\hline Longitude & $77^{\circ} 31^{\prime} \mathrm{E}$ & $33^{\circ} 54^{\prime} \mathrm{W}$ & $122^{\circ} 42^{\prime} \mathrm{E}$ & $31^{\circ} 31^{\prime} \mathrm{W}$ & $103^{\circ} 56^{\prime} \mathrm{W}$ \\
\hline Depth (m) & 0 & 2275 & 1365 & 980 & 2630 \\
\hline \multicolumn{6}{|l|}{$\mathrm{pH}$ for growth } \\
\hline Range & $5.5-7.5$ & $4.5-8.5$ & $5.0-7.4$ & $5-9$ & $5-8$ \\
\hline Optimum & 6 & 6 & $5.5-5.8$ & 7 & 6 \\
\hline \multicolumn{6}{|l|}{ Temperature for growth $\left({ }^{\circ} \mathrm{C}\right)$} \\
\hline Range & $45-70$ & $35-65$ & $30-70$ & $25-65$ & $45-70$ \\
\hline Optimum & 60 & 60 & $55-60$ & 55 & 65 \\
\hline \multicolumn{6}{|c|}{$\mathrm{NaCl}$ concentration for growth $(\%, \mathrm{w} / \mathrm{v})$} \\
\hline Range & $0.8-4.6$ & $1.0-6.5$ & $1.0-5.5$ & $1.0-4.5$ & $1.0-5.0$ \\
\hline Optimum & 2.6 & $3.0-4.0$ & $3.0-3.5$ & 2.0 & 3.0 \\
\hline Maximal doubling time (h) & 1.44 & 1.9 & 0.8 & 1.7 & 0.35 \\
\hline \multicolumn{6}{|l|}{ Utilization of: } \\
\hline Casamino acids & + & - & - & - & + \\
\hline Casein & + & + & - & - & + \\
\hline Cellobiose & + & - & - & $(+)$ & $(+)$ \\
\hline Galactose & + & - & - & - & $(+)$ \\
\hline Glucose & + & - & + & + & $(+)$ \\
\hline Pyruvate & + & + & - & + & - \\
\hline Starch & + & - & + & + & $(+)$ \\
\hline Tryptone & + & - & + & + & + \\
\hline $\begin{array}{l}\text { Growth without electron } \\
\text { acceptor under } 100 \% \mathrm{H}_{2}\end{array}$ & + & + & $+\dagger$ & - & - \\
\hline Tolerance of $\mathrm{O}_{2}$ & $<4 \%$ & $<4 \%$ & Obligate anaerobe & $\mathrm{ND}$ & $\mathrm{ND}$ \\
\hline $\begin{array}{l}\text { Sulfur compounds that } \\
\text { stimulate growth }\end{array}$ & $\mathrm{S}^{0}, \mathrm{~S}_{2} \mathrm{O}_{3}^{2-}, \mathrm{L}-\mathrm{Cys}$ & $\mathrm{S}^{0}, \mathrm{~S}_{2} \mathrm{O}_{3}^{2-}, \mathrm{L}-\mathrm{Cys}$ & $\mathrm{S}^{0}, \mathrm{~L}-\mathrm{Cys}$ & $S^{0}$, L-Cys & $\mathrm{S}^{0}, \mathrm{~S}_{2} \mathrm{O}_{3}^{2-}$, L-Cys \\
\hline $\begin{array}{l}\text { DNA G }+ \text { C content } \\
(\mathrm{mol} \%)\end{array}$ & 26.2 & 28 & 28 & 29 & 29 \\
\hline $\begin{array}{l}\text { 16S rRNA gene sequence } \\
\text { similarity }(\%) \ddagger\end{array}$ & $(100)$ & 95.7 & 95.5 & 95.6 & 94.4 \\
\hline
\end{tabular}

${ }^{\star}$ EPR, East-Pacific Rise; MAR, Mid-Atlantic Ridge; SIO, Southern Indian Ocean; SOT, Southern Okinawa Trough. $\dagger$ Slight inhibition was observed.

$\ddagger 16 \mathrm{~S}$ rRNA gene sequence similarities were calculated with reference to the sequence of the novel isolate $\mathrm{MC}^{\mathrm{T}}$. 
(Fig. 1); the most closely related strains were the type strains of M. hydrogenitolerans and M. camini, with $16 \mathrm{~S}$ rRNA gene sequence similarities of 95.7 and $95.6 \%$, respectively. The positioning of strain $\mathrm{MC}^{\mathrm{T}}$ was supported by the results of the three algorithms used.

The characteristics of strain $\mathrm{MC}^{\mathrm{T}}$ are consistent with its assignment to the order Thermotogales. On the basis of the results of $16 \mathrm{~S}$ rRNA gene sequence analysis, the isolate is most closely related to the type strain of $M$. hydrogenitolerans. The two strains can be distinguished based on phylogenetic, genomic and phenotypic criteria: they share $95.7 \% 16 \mathrm{~S}$ rRNA gene sequence similarity. The genomic DNA G $+C$ content of strain $\mathrm{MC}^{\mathrm{T}}$ is lower than that of M. hydrogenitolerans (26.2 and $28.0 \mathrm{~mol} \%$, respectively). Moreover, compared with M. hydrogenitolerans, the maximum temperature for growth of the isolate was slightly higher and the $\mathrm{NaCl}$ concentrations for growth, both range and optimum, were lower (Table 1). Furthermore, in contrast to $M$. hydrogenitolerans, strain $\mathrm{MC}^{\mathrm{T}}$ used Casamino acids, cellobiose, galactose, glucose, starch and tryptone. Strain $\mathrm{MC}^{\mathrm{T}}$ is also unique regarding its isolation site. Indeed, it is the first species of the genus Marinitoga to be isolated from the Southern hemisphere, from the Indian Ocean and from a coastal thermal spring. The four previously described Marinitoga species were isolated from deep oceanic hydrothermal vents. Given the low levels of 16S rRNA gene sequence similarity between strain $\mathrm{MC}^{\mathrm{T}}$ and the other recognized Marinitoga species and the differences in physiological features (Table 1), the isolate represents a novel species of the genus Marinitoga, for which the name Marinitoga litoralis sp. nov. is proposed.

\section{Description of Marinitoga litoralis sp. nov.}

Marinitoga litoralis (li.to.ra'lis. L. fem. adj. litoralis of or belonging to the seashore).

Cells are rod-shaped, motile, Gram-negative and surrounded by a sheath-like structure. Growth occurs at 45 $70{ }^{\circ} \mathrm{C}$ (optimum $60{ }^{\circ} \mathrm{C}$ ), pH 5.5-7.5 (optimum pH 6) and $8-46 \mathrm{~g} \mathrm{NaCl} \mathrm{l}^{-1}$ (optimum $26 \mathrm{~g} \mathrm{l}^{-1}$ ). The doubling time under optimal conditions is $1.44 \mathrm{~h}$ and the maximum cell yield is $5.6 \times 10^{8}$ cells ml $^{-1}$. Anaerobic; resistant to concentrations of oxygen below $4 \%$ and hydrogen up to $100 \%$. Chemo-organotrophic; able to ferment cellobiose, galactose, glucose, glycogen, lactose, maltose, ribose, starch, brain heart infusion, Casamino acids, casein, peptone, pyruvate, tryptone and yeast extract. Sulfur, cystine and thiosulfate slightly stimulate growth and $\mathrm{H}_{2} \mathrm{~S}$ production is observed in the presence of sulfur. 16S rRNA gene sequence analysis indicated that the species is classified in the genus Marinitoga, order Thermotogales of the bacterial domain.

The type strain is $\mathrm{MC}^{\mathrm{T}}\left(=\mathrm{DSM} 21709^{\mathrm{T}}=\mathrm{JCM} 15581^{\mathrm{T}}\right)$, isolated from a coastal thermal spring on Île Saint-Paul $\left(38^{\circ} 43^{\prime} \mathrm{S} 77^{\circ} 31^{\prime} \mathrm{E}\right)$ in the Southern Indian Ocean. The $\mathrm{G}+\mathrm{C}$ content of the genomic DNA of the type strain is $26.2 \mathrm{~mol} \%$. 16S rRNA gene sequence similarity between strain $\mathrm{MC}^{\mathrm{T}}$ and the type strain of $M$. hydrogenitolerans is $95.7 \%$. Strain $\mathrm{MC}^{\mathrm{T}}$ is available by request from the 'Souchothèque de Bretagne' culture collection, strain no. 3067 (http://www.ifremer.fr/souchotheque/).

\section{Acknowledgements}

We would like to thank Dr K. Alain and P. Crassous for help with the scanning electron microscope. We thank Dr Jean Euzéby for his kind assistance with the Latin name. This work was supported financially by the Région Bretagne and the joint research unit UMR6197. The authors would like to thank the Territoire des Terres Australes et Antarctiques Françaises (TAAF), the French Polar Institute PaulEmile Victor (IPEV) and its logistical staff for assistance in the field. We thank the captain and crew of the N/O Marion Dufresne and the IPEV team for their assistance in collecting samples.

\section{References}

Alain, K., Marteinsson, V. T., Miroshnichenko, M. L., BonchOsmolovskaya, E., Prieur, D. \& Birrien, J. L. (2002). Marinitoga piezophila sp. nov., a rod-shaped, thermo-piezophilic bacterium isolated under high hydrostatic pressure from a deep-sea hydrothermal vent. Int J Syst Evol Microbiol 52, 1331-1339.

Altschul, S. F., Gish, W., Miller, W., Myers, E. W. \& Lipman, D. J. (1990). Basic local alignment search tool. J Mol Biol 215, 403-410.

Balch, W. E., Fox, G. E., Magrum, L. J., Woese, C. R. \& Wolfe, R. S. (1979). Methanogens: reevaluation of a unique biological group. Microbiol Rev 43, 260-296.

Cord-Ruwisch, R. (1985). A quick method for the determination of dissolved and precipitated sulfides in cultures of sulfate-reducing bacteria. J Microbiol Methods 4, 33-36.

Felsenstein, J. (1981). Evolutionary trees from DNA sequences: a maximum likelihood approach. J Mol Evol 17, 368-376.

Felsenstein, J. (1985). Confidence limits on phylogenies: an approach using the bootstrap. Evolution 39, 783-791.

Galtier, N., Gouy, M. \& Gautier, C. (1996). SEAVIEW and PHYLO_WIN: two graphic tools for sequence alignment and molecular phylogeny. Comput Appl Biosci 12, 543-548.

Mesbah, M., Premachandran, U. \& Whitman, W. B. (1989). Precise measurement of the $\mathrm{G}+\mathrm{C}$ content of deoxyribonucleic acid by highperformance liquid chromatography. Int J Syst Bacteriol 39, 159-167.

Nunoura, T., Oida, H., Miyazaki, M., Suzuki, Y., Takai, K. \& Horikoshi, K. (2007). Marinitoga okinawensis sp. nov., a novel thermophilic and anaerobic heterotroph isolated from a deep-sea hydrothermal field, Southern Okinawa Trough. Int J Syst Evol Microbiol 57, 467-471.

Ollivier, B. \& Cayol, J. L. (2005). Fermentative, iron-reducing and nitrate reducing microorganisms. In Petroleum Microbiology, pp. 7188. Edited by B. Ollivier \& M. Ragot. Washington, DC: American Society for Microbiology.

Postec, A., Le Breton, C., Fardeau, M.-L., Lesongeur, F., Pignet, P., Querellou, J., Ollivier, B. \& Godfroy, A. (2005). Marinitoga hydrogenitolerans sp. nov., a novel member of the order Thermotogales isolated from a black smoker chimney on the Mid-Atlantic Ridge. Int J Syst Evol Microbiol 55, 1217-1221.

Ravot, G., Magot, M., Fardeau, M.-L., Patel, B. K. C., Prensier, G., Egan, A., Garcia, J.-L. \& Ollivier, B. (1995). Thermotoga elfii sp. nov., a novel thermophilic bacterium from an African oil-producing well. Int $J$ Syst Bacteriol 45, 308-314.

Saitou, N. \& Nei, M. (1987). The neighbor-joining method: a new method for reconstructing phylogenetic trees. Mol Biol Evol 4, 406-425. 
Thompson, J. D., Higgins, D. G. \& Gibson, T. J. (1994). CluSTAL W: improving the sensitivity of progressive multiple sequence alignment through sequence weighting, position-specific gap penalties and weight matrix choice. Nucleic Acids Res 22, 4673-4680.

Wery, N., Lesongeur, F., Pignet, P., Derennes, V., Cambon-Bonavita, M. A., Godfroy, A. \& Barbier, G. (2001a). Marinitoga camini gen. nov., sp. nov., a rod-shaped bacterium belonging to the order
Thermotogales, isolated from a deep-sea hydrothermal vent. Int $J$ Syst Evol Microbiol 51, 495-504.

Wery, N., Moricet, J. M., Cueff, V., Jean, J., Pignet, P., Lesongeur, F., Cambon-Bonavita, M. A. \& Barbier, G. (2001b). Caloranaerobacter azorensis gen. nov., sp. nov., an anaerobic thermophilic bacterium isolated from a deep-sea hydrothermal vent. Int J Syst Evol Microbiol 51, 1789-1796. 